\title{
NAUMACHOCRINUS, A NEW GENUS BELONGING TO THE CRINOID FAMILY PHRYNOCRINIDE.
}

\author{
By Austin Hobart Clark, \\ Assistant Curator, Division of Marine Invertebrates, United States National Museum.
}

The genus Phrynocrinus, ${ }^{1}$ based upon a single species described from a single specimen dredged by the United States Fisheries steamer Albatross off southern Japan in $1906,{ }^{2}$ represents a unique type of crinoid structure, though its more or less distant relationship to the genus Rhizocrinus is evident. So extraordinary are the characters presented by this animal that at the time of its description a new family, Phrynocrinidæ, was created for its reception.

Recently in looking over some material from the Hawaiian Islands a curious crinoid was found which at first sight appeared to be a Rhizocrinus of the $R$. rawsonii type, but with the distal third of the stem of the Phrynocrinus type, devoid of radicular cirri and attached to a terminal stem plate. Analysis of the calyx of this new form, however, shows that the calyx, instead of being composed of enormously elongated basals bearing distally small radials as in Rhizocrinus, is just the reverse, the very small basals bearing on their distal edge enormously elongated radials. This type of calyx structure is quite unique. Certain species of Bathycrinus have very short basals; but in this genus whenever the basals are short they are always fused into a solid ring - and they are never so short as in Phrynocrinus and in this new species. The radials of Bathycrinus, though usually longer than the radials of Rhizocrinus, never become elongated as in this form. Many species of Rhizocrinus, and especially of Bathycrinus, possess more or less phrynocrinoid distal extremities to the stem, but in all cases they possess radicular cirri, never being attached. But this difference, though interesting, is of no great importance, for in certain groups, and even in single genera, some forms may be free with radicular cirri, while others are attached to a heavy terminal stem plate.

1 For the author, place and date of publication, derivation, etc., of this and the other crinoid names herein given see Proc. U. S. Nat. Mus., vol. 34 , pp. 435-542.

${ }^{2}$ Proc. U. S. Nat. Mus., vol. 32, p. 507, flg. 1, p. 508. 
Though indicating the connection between the genus Phrynocrinus and the genera Rhizocrinus and Bathycrinus, this new genus is evidently much closer to the former than to the two latter, and should be placed with it in the same family.

This is the first stalked crinoid to be described from the Hawaiian Islands; and it is interesting to note that it is so closely related to a Japanese form (Phrynocrinus), and, moreover, that it possesses a lesser degree of specialization that the latter ${ }^{1}$ for from the evidence at hand it appears that the crinoid fauna of southern Japan was derived largely from that of the South Sea Island region by way of the Hawaiian Islands, and not from the lands lying directly to the southward.

\section{NAUMACHOCRINUS, nevv genus. ${ }^{2}$}

Genotype.-Naumachocrinus hawaiiensis, new species.

Diagnosis. - Stalk attached distally to a terminal stem plate as in Phrynocrinus, entirely without radicular cirri; distal third of stem robust, the columnars resembling those of Phrynocrinus, but slightly longer; proximal two-thirds of stem much more slender, resembling that of the larger species of Rhizocrinus, such as $R$. weberi.

Calyx cylindrical, greatly elongated, twice as long as broad, resembling in general appearance that of Rhizocrinus rawsonii or $R$. weberi; but the basals are exceedingly short, low triangular, over three times as broad as long, just in apposition at their lateral angles, and the radials are enormously elongated, about three times as long as their distal breadth, the relation between these two circlets of plates being just the reverse of that characteristic of Rhizocrinus.

NAUMACHOCRINUS HAWAIIENSIS, new species.

Stem.-The stem is $237 \mathrm{~mm}$. long, and is composed of 60 columnars, the distalmost attached to the remains of a heavy terminal stem plate resembling that of Phrynocrinus; the distal $75 \mathrm{~mm}$. of the stem is composed of 12 massive columnars of the type characteristic of Phrynocrinus, but proportionately longer. The distalmost columnar is $6.5 \mathrm{~mm}$. across the expanded ends, which are very narrowly oval, the long axes being at right angles to each other, and $6.5 \mathrm{~mm}$. long; about its center runs a more or less irregular broad raised band; the following columnars are similar, very slowly decreasing in size, the tenth (from the terminal stem plate) being $4.5 \mathrm{~mm}$. across the very narrowly oval ends and $6 \mathrm{~mm}$. long, and the eleventh $4.5 \mathrm{~mm}$. across the distal and $4 \mathrm{~mm}$. across the proximal end, and $5.5 \mathrm{~mm}$. long; the twelfth is $4 \mathrm{~mm}$. across the distal and $3 \mathrm{~mm}$. across the proximal end, and $4.5 \mathrm{~mm}$. long; the proximal end is very broadly oval, but the distal end is narrowly oval like the proximal end of the eleventh 
to which it is attached; the sides are strongly convex, the maximum height being just above the center; the following columnars are small and short, with strongly and evenly convex sides, $3 \mathrm{~mm}$. long and $2.5 \mathrm{~mm}$. across the ends; their median diameter, at the height of the convexity, is $3 \mathrm{~mm}$; t there is very little difference between the two axes of the ellipses forming their proximal and distal articular faces; after about the twenty-fifth columnar from the terminal stem plate the length begins to increase very gradually and the sides to become parallel, later assuming a slight median concavity like the columnars of the large species of Rhizocrinus, the thirtieth from the terminal stem plate being $3.5 \mathrm{~mm}$. in length and $2.5 \mathrm{~mm}$. across the ends, the forty-fourth $4 \mathrm{~mm}$. in length and $2.3 \mathrm{~mm}$. across the ends, the fiftieth $5 \mathrm{~mm}$. in length and $2.3 \mathrm{~mm}$. across the ends; the first three columnars just beneath the calyx are exceedingly short and discoidal, as in Bathycrinus, but beyond these the length rapidly increases.

Calyx.-Basals five, resembling those of Phrynocrinus nudus, low triangular, slightly over three times as broad as high, in lateral apposition all around the calyx through their slightly blunted lateral angles; their length is $3 \mathrm{~mm}$. to $4 \mathrm{~mm}$., their basal (proximal) width about $1.5 \mathrm{~mm}$.

Radials five, enormously elongated, about three times as long as their distal width, forming a compact cylinder as do the basals of Rhizocrinus weberi; each radial is about $5 \mathrm{~mm}$. long in the median line, about $1.5 \mathrm{~mm}$. broad at the base and about $1.7 \mathrm{~mm}$. broad distally, so that the radial circlet is almost a perfect cylinder; its diameter is about $2.5 \mathrm{~mm}$. at the base (the same as that of the basal circlet) and $2.8 \mathrm{~mm}$. distally.

Superposed upon each radial is a first brachial which is about 1.3 $\mathrm{mm}$. in median length and $1.4 \mathrm{~mm}$. broad, the lateral edges straight and parallel, the distal edge straight, the proximal edge strongly convex, corresponding to a strong concavity in the distal edge of the radial as in Rhizocrinus.

Locality.-Albatross station No. 4187; off Kauai (Hanamaulu warehouse, S. $38^{\circ} 45^{\prime}$, W. $8.1^{\prime}$ ); depth, 508-703 fathoms; bottom temperature, $40.0^{\circ} \mathrm{Fahr}$; bottom, gray sand and foraminifera. One specimen, the type of the species.

Type.-Cat. No. 29573, U.S.N.M. 


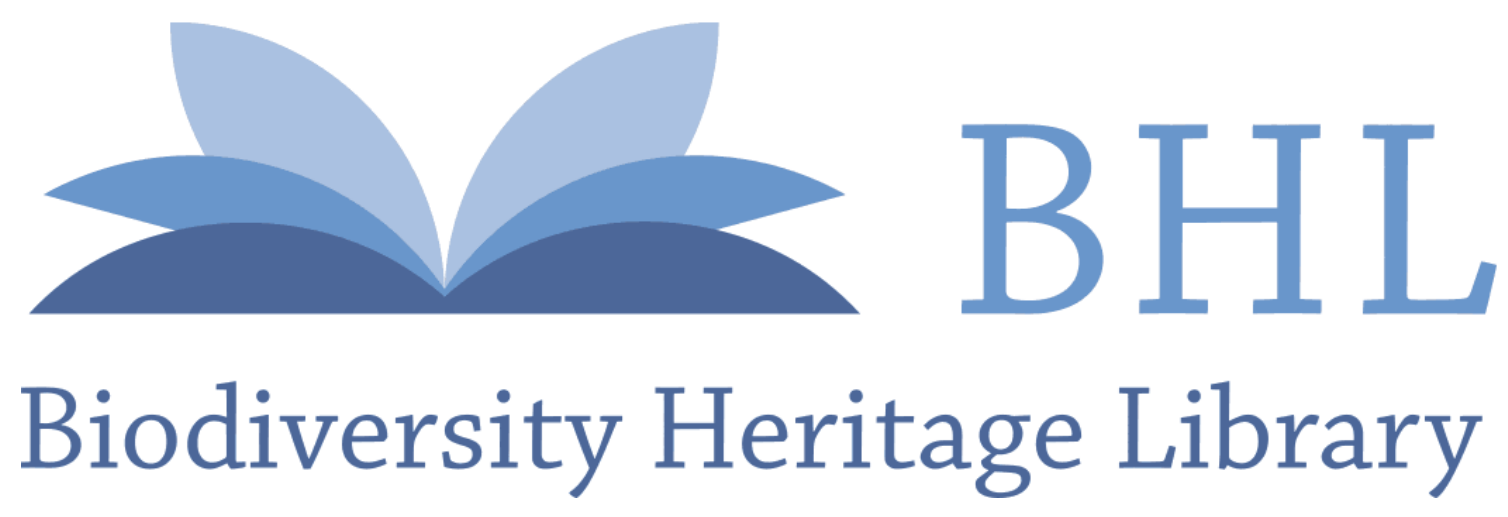

Clark, Austin Hobart. 1912. "Naumachocrinus, a new genus belonging to the crinoid family Phrynocrinidae." Proceedings of the United States National Museum 42, 195-197. https://doi.org/10.5479/si.00963801.42-1895.195.

View This Item Online: $\underline{\text { https://www.biodiversitylibrary.org/item/32500 }}$

DOI: https://doi.org/10.5479/si.00963801.42-1895.195

Permalink: https://www.biodiversitylibrary.org/partpdf/13660

\section{Holding Institution}

Smithsonian Libraries

\section{Sponsored by}

Smithsonian

\section{Copyright \& Reuse}

Copyright Status: NOT_IN_COPYRIGHT

This document was created from content at the Biodiversity Heritage Library, the world's largest open access digital library for biodiversity literature and archives. Visit BHL at https://www.biodiversitylibrary.org. 